\title{
Foundational issues surrounding professional training of speech and theatre experts at universities in the RSA
}

\author{
BLIVE SCHLEPERS
}

Deparment Speech and Drama, PU for CIILE, Potchefstroom

\section{ARSTRAC:T}

When in the course of the thirties in the English and in the sixties in the Afrikaans theatre in the RSA "an urgent need" developed, the university lecturers, $10 \mathrm{my}$ mind, blindly assumed that there acas a demand for well-trained "performing theatre artists" without investigating or researching the matter properly, and they eslablished "drama" departments at their universities "lo train actors for the profession". By choosing to follow the objectives of the independent drama schools of the English. "but at a university", they abused the nature and the function of the university and so ultimately landed in a cul-de-sac.

The American drama lecturers, on the other hand, who had already looked at the whole malter of "Drama" at the university since 1890, decided that the central problem in the world of the theatre in the (SSA was not a lack of well-trained actors, as was generally accepted. but a lack of "creative and original theatre artists", among whom the playuright was certainly the most important, and they established Drama departments at their universities "to train playwrights". In this way they pointed the way for growth and development for all "Theatre departments" in the world.

If, in those days, we had bcen clever enough to learn from the American experience, and to learn from their mistakes, to lake, from that what was good and to have adafled all this 10 mur oun needs and circumstances, then perhaps today we could have been "with" the Americans in the forefiont of "Liducational and Academic Thealre", and then we would not have been experiencing the cultural drought and the scarcity of new South African plays. The fact that we went to the English to learn about "drama" training at our uninersities is, 10 m!' mind, one of the greal causes of our present difficulties: confusion of concepts, incorrect terminology and undefined objectives.

Kivers, $46(4), 1981$ 


\section{Training of speech and theatre experts}

Theatre training in the Republic of South Africa is mainly centred in the "drama" departments of the universities. The eflicacy of this arrangement is generally questioned, because according to the essential nature of the university it is not the purpose and the task of the university to give professional training as such, and according to the professional theatre itself the university is not the place where actors should be trained. And yet we find the scemingly paradoxical situation that aspiring nurses, engineers, clectronics experts, home economists, journalists, teachers, radio announcers, dramatists, directors and actors are found at South African universities. Have the universities denied their original principles by allowing this? If not, why did the authorities then approve the establishment of, among others, "drama" departments at the universities: mercly for the sake of cultural guidance to the students, to entertain the masses on and around the campus, or to serve as a showcase for the university in question?

According to the erstwhile rector of the University of Stellenbosch, Prof: H.B. Thom, the first Afrikaans "drama" department was established at that university in 1961, because the University "realized the urgent need lor a proper training of performing theatrical artists" (1966)!

If this is true - that these departments have been established purcly to train actors for their profession - what will become of these departments when the profession has become saturated? There has already bcen a call fiom the theatre profession that the "far too many university drama departments should be reduced in number. This is unwise expenditure of of money. There are ten times as many students within these departments as enter the profession each year. lewer drama departments will lead to a better quality of training. Four drama departments should be able to do what eight are doing now. Each department spends a fortune on lacilities", and "even if all the aspirant actors were given the best training in the world, there could never be sulficient work here for them all when they graduated" (Venables, 1976).

1. The first "drama" department at an English-language university in the RSA (Cape Town 1931) was based on the model of England's independent drama schools. These drama sehools have the exclusive function of training actors for the profession (cf. Schecpers, 1978, pp. 25, 34).

2. Mannie Manim (the Icader of the independent Company of the Market Theatre in Johannesluwg) during the symposium on Die toekoms dan die tealer. 23-28 August 1976, in the (ivic 'Theatre in Johannesburg (Rapport, 29 August, 1976, p. 21). 


\section{Scheepers}

If then it is against the essential nature and function of the university to train actors, and it the profession can absorb only a limited number of graduates per year anyway, is it then justified to expect of the universities to support such "expensive" departments? 'The prolessional theatre is also, in the last analysis, not at all satisfied with the "results" and the "products" produced by the "drama" departments (Scheepers, 1981, pp. 33-34). Do the drama departments then have any right of existence, any purpose, any olject?

It is clear that the eight "drama" departments at the universities in the RSA arc in the midst of a crisis. As long as the various sectors of society believe: that the "drama" departments merely train actors and then ostensibly only expect such training of them, and as long as the "drama" departments fecl that they have to comply unquest ioningly with these demands and expectations, the chances for growth, development and extension of these departments should be regarded as being zero: the professional theatre will continue to demand for itself the right to prescribe to the departments of "drama" when it comes to the training of actors; educational authorities will remain under the false impression that the "drama" departments intend to make "actors" of" all schoolchildren, and will still refuse to institute certain "drama" subjects at the schools; the general public and the parents of intending students will remain hostile to the idea that their children should study in these departments; the "drama" departments will be further emptied because the students, especially the male students, who are not specifically interested in a carecr in the theatre, will avoid study at these departments; the university authorities will make further cuts in the stall, the funds, the time and the facilities of the "drama" departments (Scheepers, 1980, pp. 37-41). The "drama" departments will then, slowly but surely, bleed to death.

What should the "drama" departments then do under these circumstances? How did other countries tackle - and solve - these problems?

\section{ENGLAND}

The eight "drama" departments at universities in England have also landed in a dilemma and have thus found themselves in a cul-de-sac. There the problems are different from those encountered in the RSA, however. As a resule of the fact that lingland has a sufticient number of drama schools to train actors for the profession, it has never been necessary for the "drama" departments over there to worry about the needs of the profession. In an effort not wencroach on the terrain of the independent drama schools, 
Training of speech and theatre experts

they find it very difficult to formulate their own objectives, and to motivate and justify these. How does one just ify drama (which means action and which is written with the purpose of being cnacted on a stage) as an academic subject if one does not want to acknowledge the stage production as an academic activity? England and Europe have been trying for years to succeed in this, but up to now they have had remarkably little success ${ }^{3}$.

The resultant theoretical speculations about the history, milieu and style, about acting and directing theories, about the technical aspects and skills and purcly literary analyses of plays - as they are done in most "drama" departments in England and Europe at the universit ies - are, 10 my mind, senseless, a waste of time and unscientific, because the true object of study (the stage production) docs not constitute the point of departure and the focal point of their study and rescarch.

The ivory tower element at these universities is also still strong as a result of their clinging to traditional and classical principles. They regard the university as a place where a handful of selected, privileged intellectuals (a group which, apparently, does not include theatre lecturers!) kecp themsclves busy with the theories and the philosophies of their own lield of study. They support the idca that tertiary education for the masses should take place at colleges for advanced training or at separate professional training institutions.

In 1948 the University of Oxford sent a commission to the USA to investigate "drama" studies at American universities. In their report: Report of the Oxford Iniversity Drama Commission (p. 6) they indicated that although they were very impressed with the work done in the field of theatre at the American universitics, they regarded it as being below the dignity and the traditions ol the University of Oxford to inst itute a "drama" department at this university, "since the technical aspects of scene-construction, costumcmaking, and the like, which are taught in American universities, could not prolitably be included here". They did believe, however, that there was full justilication "for the study of the drama as it is conducted in the American universities, and we think that it has a benelicent inlluence on the students themselves and, ultimately, on American culture and standards. It seems

3. In 1978 David Bradby, the chairman of the Drama Board of Studies at the University of Kent at Canterbury still found it necessary, in an article Drama in the universities (p. 30) to try and prove that Drama was an independent discipline.

Cl. also the draft suggestion lien autonome geherprogrammeerde sfudie Theateruptensrhap (Aug./Oct. 1976, unpublished) of the Dutch universities in Scheepers, 1978, pp. 174-82) and "Dic huidige stand van teatcropleiding aan die Europese universiteite" (ilıd., pp. 182-7) 


\section{Scheepers}

to us also that there are universities in our own count ry (more closely linked than ()xford to the regions to which they belong) which might study, and perhaps in part adopt, the methods of some of the American universitics. Thinking, however, as we do, that Oxford has the distinctive lunction of maint aining the standards of scholarship, learning, and rigorous thinking at the highest levels, we do not think it should follow the road of the development which we have studied in America".

What was this "road of development" to be discerned at the American universities, and which Oxford disclained?

\section{AMERICA}

Although Theatre as such has existed from the earliest times, the theatre, its theory, its history and practice have only been considered worthy of academic study trom 1925 onwards. 'This was also only true, initially, of American universities. The Americans are regarded as the pioneers, and are still regarded as the foremost exponents and as the leaders in the field of cducational and academic theatre in the world today".

The "epic struggle" of a small group of university lecturers in America - "realist ic irlealists", as they are called by NTC (Gard, 1968, p. 73) - to have thealre acknowledged as worthy of scientific study at the universitics is wcll-known (ibid):

"It was not easy to bring this sprawling, suspect, and often misunderstood hastard within American college halls. 'There were no forcign precedents, no prototypes, to serve as models or give the loundling academic sanction. University laculties and presidents held out against inclusion of the study of theater as long as they could; and when they could hold out no longer, they charily conceded a tiny spot in the curriculum for dramatic litcrature".

4. In the light of this it was highly upsetting and shocking to discover in the Report of the (Nicmand) Commission of Inyuiry to the Performing Arts (1977) that practically all Western countries apart from the IS $A$ have been visited to lind information about thratre training at the unitersities! 'The RSA is still committed to invite "experts" in this fielel from Eugland to give lectures here, while their American peers are far advanced in this field as a matter of course. 


\section{Training of speech and theatre experts}

In 1924 a I) prartment of Drama was inst ituted in the School of Fine Arts at Valc University with the express purpose of training uriters for the theatre (plaperights). This department, and many others across the USA which came into being quickly, were the only university departments in the world which, to my mind, can justifiably lay claim to the name of Drama departments

The University of Yale soon realised, however, that playwrights could not be trained without stage productions. The task facing the Drama departments in the USA now was to convine their university authorities of the necessity that all training for the theatre had to be studicd from the point of view of the practical doing and acting on the slage. This is after all the only scientific and academic manner in which one can penctrate to the core, the essence ol drama, they contended ${ }^{6}$.

There are basic differences between the norms and standards in England and in Amcrica as to which lields of knowledge constitute a science', and which ficlds are therefore decmed a fit subject for study at a university. The theatre courses of the Amcricans (the sciences studying aspects of the theatre: Theatre Science, Theatre Arts, Theatre Crafts, etc.) serve the cause of science: the theatre is studied from the point of departure of doing and acting which can at the same time be properly theoretically founded (academic) but they do believe at the same time that no theory can be sound unless it is based on a study of the living reality of the field of study (in this case an actual stage production). The stage production is then not merely a practical application of already exist ing theories, but the reality that is studicd and against which one tests things to arrive at new theories, insights and lindings. The botanic gardens and the hothouses of botanists are concrete realities used for the development of theory - after the actual botanical material has been studied as the field of investigation. Have you ever secn a botanist without

5. In these departments the written text (the play) was studied in an effort to train playwrights. When playwrights were later trainect by nicans of a stage production (the "living text" on the slage) lliese departments became Theate depatments. The Drama departments which retained the name are calied that for historical or traditional reasons.

6. Prof. J.R. Brown who was appointed to the third chair in Jrama and Thealre Arts at an English university (Birmingham, 1967) used this argument as the point of departure in his inaugural lecture, $A$ uniersity and the theatre. His post was vacant within five years! 


\section{Scheepers}

plants? How then can a theatre scientist be trained without a theatre?

In the sane way that the realisation dawned in the twenties that playwrights could not be trained without stage productions, so the realisation came in the sixties that audienes and theatrical artists could not be cultivated without excellent stage productions. In order to attain an initial acactemic objective (viz. to train playwrights), an ostensibly unacademic activity (viz. stage production) was linally granted academic status. And the I rama departments of the Americans became Theare departments.

Because drama was studied on the stage, the Americans suddenly found themselves in the situation where they were able not only to train playwrights, but also actors, directors, designers, technicians, theatre and stage managers, teachers and lecturers. The training of these professionals had further "un"-academic implications and courses: the construction of décor, the making of costumes and props, stage make-up, wig-making, practical work in lighting and sound ellects, etc. The study of these technical aspects on stage in turn had the eflect that scientists of the theate luad the living reality right in fromt of them for the purposes of their study and rescarch, and theatre scientists with a total knowledge of their lield of study could be trained: playrerights, theatrical historians, philosophers, reviewers and crities. And this is the real purpose which a Theatre departuncent at a university should have, and there is no shorter, cheaper or easier way to arrive at this final objective ${ }^{9}$.

7. Dr. J.J. Venter of the Department of Philosophy at the University of Fort Hare helped me with this foumulation. The Amerieans themselves do not state it so clearly anywhere (ct: Siluecers, 1978, p. ix and 300$)$.

8. Thanks to this pionerering work we have expert handbooks from America today to use in out "drama" departments!

9. The theatre lecturers in the Netherlands reproach the ir Academic (ouncil that they have no sciemidie grounds not to acknowledge Theatre bience as an indepenent discipline al the

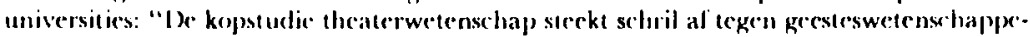
lijke disc iplines, die als object van onderzock de becldende kums of muriek hebben. Dere discipline's zijn al lange tijel vollelige studies. Es zijn geen matschappelijke of wetense haphpelijke argumemen of criteria die dit versehil in status met theaterwetensehap zouden recheatudigen". They leet that the Arademic Council is shying away from the great linancial expendieure and the organizational problems which theat rical productions would

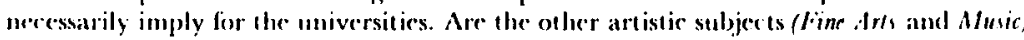
perhays more ace plable for the universit ies purely because it is cheaper and rasic to supply

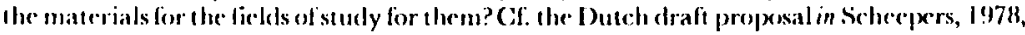
Pp. 174-182. 


\section{Training of speech and theatre experts}

Today there are more than 1200 Theatre departments at universities in the USA. At the undergraduate level there are twice as many students of theatre courses at US universities as there are students (generally) at all the universities in the RSA (Scheepers, 1978, p. 12). They have at their disposal more than 19.38 well-cquipped theatres. The more than 5306 lecturers in theatre fill a leading role in the Theatre in the $\mathrm{USA}^{10}$. In contrast with the Calouste Gulbenkian Report in England, DAC'T (1976, p. 91) gives the following optimistic picture of theatre training at the universities in the USA: "This directory presents a comprehensive report on a still comparatively young and growing field in American higher education: the educational theatre... In general, the field of theatre education appears healthy and growing. Since the first edition of DACT was published in 1960, there cont inues to be a trend toward greatcr specialization in curriculum; more play production activity; and continued increases in enrollment".

\section{SOUTH AFRICA}

South African universities have the same capacity as the American universities to adapt to a continually changing community and world to the advantage of the people and without loss of its own sovereignty. When an urgent need in a certain field of society occurs, it is possible alnost immediately to make provision for this need in the university curriculum. This is no more than fair. But it is the duty of every university in the RSA to see that these adaptations do not assume ridiculous proportions - as does happen at the weaker universities in the USA. Are the subjects offered in the "drama" departments in the RSA scientifically and academically acceptable? Do they conform to the nature and the function of the university?

When, in the English-language universities in the RSA in the thirties and the Afrikaans-language universities in the sixties, an "urgent need" developed, the university lecturers, in my opinion, blindly assumed that there was a need for well-trained performing theatrical artists (cf. p. 345 above) without researching the matter properly, and they instituted "drama" departments at their universities to train actors for the profession. By aiming for the objectives of the independent drama schools of England at universities in South Africa they damaged the essence of the university and so landed

10. These statistics represent only the Thealrical Arls and Science Departments in the USA. The statistics of Speech Communications, Interpretation, Logopedics, Educational Theatre and Film and TV departments are not included here. CC. below. 


\section{Scheepers}

inevitably in a cul-de-suc.

American theatre lecturers, on the other hand, who have already been looking at the question of Drama at the university since 1890, decided that the crucial problem in the world of the theatre in America is not a lack of well-trained actors as is generally assumed, but of creative and original theatrical artists, among whom the playwright is certainly the most important, and they instituted Drama departments at their universities to train playwrights and so pointed the way for all Theatrical Arts departments in the world.

Has South Africa been negatively infuenced by the Oxford Report, as a result of our being so bound to England and what happens in England 'I? Has this affected our view of theatrical training at the American universities? 'To my mind a thorough investigation into theatrical training should have becn undertaken by a South African Commission in 1949-1950: an invest igation into theatrical training as practised in American universities ${ }^{12}$. Then the picture of theatrical training in South African universities would have been very diflerent.

The problems inhibiting the proper functioning of the eight "drama" departments at universities in England do not exist in South Africa. We do not have independent drama schools. Our universities are not ivory towers which still cling to the traditional views governing the choice of subjects suit able for studying at university level. Theatre science is a "new" science and does not want to fit comfortably into the pattern of the "old" universities. 'The universities in the RSA, just like those in the USA, are not bound by tradition, and they are free to participate in the modern educational methods of the "new" world.

11. It is pathetic to see the way in which the universities in the RSA are cutting their own throats by openly lenting the Technikons (alter the example of Great Britain!) gain ground while the university lecturers in lingland and in Europe are doing their best to convince their university authorities of the validity of the American view of university training. It is no wouler that we are 25 years behind the limes! $\Lambda$ ll "progress" in the RS $A$, to my mind, takes place accerding to preseriptions and metheds which have already become obsolece in England and in Europe and are in the process of being discarded.

12. In 1950 the erstwhile secretary of the South African Academy for the Arts, Dr F.C.L. Bosman, made a study of theatre in the USA. He received a grant from the National Council for Social Research in 1949 to enable him to undertake this study tour. His report (1952) about the field of University theatre was very vague, superficial and unacadrmic, and not of much practical value. 


\section{Training of speech and theatre experts}

If we had been quick enough in the past to learn from the experience and the mistakes of the Americans, and to have taken from them that was useful to adapt to our own circumstances as a basis for building our own edifices, then perhaps today we might have been in the forefront of educational and academic theatre along with the Americans. Then also we would not now be experiencing the cultural drought and the need for new South African plays. The lact that we went to England to find inspiration for training in "drama" at our universities, is, to my mind, one of the prime reasons for our present problems: conceptual confusion, mistakes in terminology and undefined objectives.

The South African unversities fortunately have the same capacity as the American universities to change courses in the curriculum on a continuing basis to adapt to the most recent and most modern findings as regards teaching content. It is thus not necessary for the "drama" departments in the RSA to remain in this cul-de-sac, but then we have to be ready and willing to make certain changes and adaptations.

\section{QUO VADIS, SOUTH AFRICA?}

The "drama" departments at the South African universities cannot evade their responsibilities towards the profession. They cannot refuse students professionally oriented study courses, because they will then dic off. For $80 \%$ of our lives we are involved in our professions. The "drama" departments also have a responsibility as regards the professional aspirations of the students who come to the university to prepare and/or to be trained for a profession (Robbertse, 1970, p. 373).

But their first responsibility is to conform to the "exalted" aims of the university before giving in unconditionally to the "alssurd" demands of the profession (Scheepers, 1981, pp. 31-46), which, for example, demands a fully trained and finished product from the university.

The university refuses to deliver technically and mechanically trained products on demand to the profession. The "drama" departments have to refuse to lower the acting profession and to reduce it to the level of an operator. Apart from the fact that this is in conflict with the nature of the university, the Theatre in the RSA does not need uniform, regimented and drilled factory products in its corps of actors. The training of the actor at the university should be such that he should ultimately be able to arrive at his own design of a scientific and independent method to analyse at role and to 
Scheepers

interpret it on stage, so that he ean const ruct a concept of the nature, essene and structure of his sul,ject as art and as a science.

\section{DO THE EXISTING “DRAMA" DEPARTMENTS SUPPLY ONLY ACTORS' 'TRAINING?}

At the universities in the RSA the whole field of Speech and Thratre (and sometimes film and $I I$ as well) is covered by one single academic depantment (cl. Siperech as an academic subject discipline [Botha, 1969, pp. 15-22]). These departments have become known in the RSA (after the example of lingland) under the conglomerate name of Speech and Drama defar/ments, and then became known simply as "drama" elepartments.

Speech and Drama as a field in the RSA represents a very wide and divergent lield of study (Speech/Theatre/Film and TV). It would be impossible to fullil all the demands and objectives of the whole field within the framework of one university department. In the USA this work is done by six different university departments.

In 180.5 already Speech (R hetoric and Puldic Speaking) was acknowledged at lhe Iniversity of Harvard in the USA as a scicentific and academic subject in its own right (Wallace, 1954, p. 155). (It says a great deal for the aims of this subject that the first professor, John Quincy Adams, later became the sixth president of the USA.) As far as I could determine, the first independent Speerh Depertment in the USA was inst ituted at the University of (jeorgelown in Washington D)( (I)AC: 1 , 1976, p. 18). From the same source it appears that before 1900 at least 23 and before 1919 a further 53 speceh Departments came into being at universities in the US $\Lambda$. After more than a century these Speech Departments are still growing at an incredible tempo. Through the years there have been many shifts in emphasis and changes as regards the names of the departments, the nature and the methods of the speech discipline, but the primary objective of Speech as an academic discipline was, and still is, to establish a community in America that is conscious of specch and is well-spoken itself.

The tollowing subjects developed out of the original Spech departments ${ }^{13}$

13. Spereh difuromems exist exclusively at universities in the [1SA (13rown. 1967, p. 3). Prof. Siteddon was the liest person in the RSA who had the same objertives as those of an 


\section{Training of speech and theatre experts}

so that today cach one is an independent academic department in its own right - sometimes in a School of Specch (cf. Northwestern University): Speech Communication; Interpretation; Speech Education or Thealre-in-Lducation; Logopedics.

Speech departments were therefore at least eighty years old. Speech was an acknowledged, compulsory and established school subject, the $A$ merican nation was sensitive to specch, well-spoken and educated in Speech before the first Drama Department in the USA was established completely independently in 1925

In the sixties the Americans' Drama Departments became. Theatre Departments. Today the Americans also have separate Film and ' $\mathrm{V}$ ' departments and voilà - six independent departments in practically every university in the USA, cach with its own staff, students, facilities, objectives and methods.

Apart from logopedics, which is oflered in the Faculty of Science in some South African universities, and Film and TV (ollered in some local universities within the "drama" department or in conjunction with the Department of Communication and/or centre for Audiovisual and Media T'raining) the exist ing "drama" departments in the RSA are trying to fulfil all the needs and objectives of the above. It is essential and important work. Who else will do it if the existing "drama" departments do not do this work?

13. (Continued) American Speech Department. Apparently she was not aware of the fact that the Americans alteady had Speech departments at their universities a full century before the department at the University of Natal rame: into existenre. It would have lacilitated her task greatly in gaining recognition for Speech at her university in 1949-51. She would not lave needed to seck a way "to understand Speech on levels that would be acceptable to the "academic mind"", because the Americans opened the way $(1978$, p. 11$)$. Prof. Sneddon in reality established the first Speech Department in the RSA, but went beyond her purpose by calling it a departencent of Speech and Drama. She delinitely refers to England and South Africa when she says (ibid., p. 12): "Such a definition of Spech was not known in any academic ciecte lifty years ago, but today, however reluctantly, it is lecoming widely accepted in academic circles and consequently Speech and I trama is being implemented as an academic discipline in a great many Universities". I fear that the Speech/Speceh training which is implicit in the nomenclature of the "drama" departments and diama schools here and in England is mainly meant for the training of actors and oral interpreters, and it has little or nothing to do with the Americans' Speech as a disciplinc, or what Prof. Sneddon had in mind with "Speerh and Drama". 


\section{Scheepers}

It goes without saying that each department cannot do everything itself, and everybody is forced to stress one or two aspects at the expense of the others. Lach "drama" department in the RSA is in reality, depending on who is in charge, either a Speech Communication deparmment (such as the Iniversity of Natal) or a 7 heatrical Irts depar/ment (such as the Universities of Cape 'lown and of Precoria) or a Film and $T V$ department (such as the Universities of the Witwatersrand and of Grahamstown) or a Theatre-in-Education department (such as the I Iniversity of Stellenbosch and of Blocmfontein) or an Inderprelation and Theatre. Science dcpartment (such as the University of Potchefstroom). And yet all these departments are called Speech and/or Drama departments, and nobody, except perhaps they themselves, will know what is being done within each department ${ }^{14}$.

The lumping together of all these different activities under the umbrella term of ispech and I)rama causes a great deal of confusion as regards objective and methods, not only within the "drama" departments themselves, but also in the minds of anyone looking at these depart ments and their activities.

The time for rellection, critical evaluation and intensive research on the foundations, objectives and activities of "drama" departments, and "drama" courses at universit ies has now arrived. With reference to the question included in the questionnaire (Scheepers, 1978, p. 189) as to what the general objective is of the training offered in the "drama" departments, it appeared that most heads of departments have not yet themselves done adequate rescarch as to the nature and the function of the university in general and as to the nature and the function of the specific university of which his "drama" department is a part.

It is essential for the growth and the development of the "drama" departments that the lecturers should fill their places as academics, and it is the duty of each university offering "drama" subjects to reflect ancw on the immediate aims and objectives of its own courses.

It is of even more importance that these findings and information should be passed on to the profession and to all those concerned, so that there could be

14. These names i derlured from replies to questionmaires (Scheejxers, I978, pp. 188-252), from brochures, visits and conversations. They represent the impression I received as an outsider abent the work lecing done in each department. 


\section{Training of speech and theatre experts}

no misunderstanding as to the precise objectives and aims of any given "drama" department. It is for this purpose that the academic theatre journal Teaterforum was established in 1980.

The process of enlightenment should, to my mind, already be initiated with a look at the namings of the "drama" departments. Various heads of departments (cf. Sneddon [1978] and Botha [1964 and 1970]) have already protested strongly against the idea that "Speech and Drama" students are trained to become actors. Their statements and arguments, however, have been largely ignored, because in the RSA "drama" training, as a result of the way in which it was originated at the universities, has become synonymous with "actor" training. How can this be put right?

\section{A POSSIBLE SOLUTION}

The abused and misleading word drama (most peoplc in the RSA are hostile and prejudiced about the concept anyway!) should, to my mind, disappear from our vocabulary as soon as possible. Every time we use this word, a better, more descriptive and more applicable word suggests itself quite readily. Why should we persist then to use a word/term which only causes problems and misunderstandings while it could easily be replaced by a better one?

Each university in the RSA should have the following two departments: A Speech communication department and a Theatrical Science department ${ }^{15}$. Until such time as the university authorities realize and accept the necessity of this, cach existing "drama" department will have to separate its work into two clear divisions.

\section{THE SPEECH COMMUNICATION DEPARTMENT}

The general objective of a department like this should be to create a community in South Africa conscious of the importance of specch and interested in becoming well-spoken. The following subjects should be oflered:

15. A few views on this point in the article diller from those to which I subscribed in my thesis. The difference in approach should be ascribed to the fact that after 19781 did not stop) thinking about the whole matter of "drama" training at the universities. 


\section{Scheepers}

\section{Speech communication}

where aspiting polit icians, ministers, judges, teachers, lecturers, oral interpreters, business managers, conference chairmen, public speakers, actors and rarlio anmonncers - in short, everybody who carns his daily bread througli speaking - can learn to say what they want, what they mean, to use their voices correctly and to develop their speech and expressive abilities. Speech (iommunication $I / I$ should not be a prolessional qualification but an acadimic qualification for the $B \Lambda$ degrec. This course, basically intended as background, and a lormative course, would then not train a student for any specilic profession. It merely prepares the student to become a better teacher, announcer, speaker, actor, $P E R S S O$. N who can communicate ${ }^{16}$.

\section{Oral Interpretation}

Interpretation of the works of literary art in verbal form, of which dramat ic litcrature is only a small subdivision, to my mind constitutes the art form of the craft of Spresch ${ }^{17}$. The small handful of students who have mastered the technigues and the skills of good spech will have the opport unity here to use their talents. Oral Interpelation III could serve as preparation for, amongst other, the following prolessions:

(a) oral interpreters of the literary work of art (such as acting for PACT Playwork);

(b) radio artists and announcers;

(c) dubling lor $\mathrm{l} \mathrm{V}$; and

(d) all teachers lecturers.

\section{Speech Education or Theatre-in-Education ${ }^{18}$}

All primary schools in the USA use "creative dramatics" to explain learning content, even maths, to the pupils. Technically this is not, of course, a theatrical activity, because the pupils improvise the material, and it is not

16. Juelged by the paper Prol. Snedden read at the drama conference at Pretoria in 1975 (1978 pp. 9-21), she strove to allain the alove objeceives" brings" (c1. alwo. Swart, 1978, p. 37) at the [ Tuiversily of Natal. 'Th is is also the content of the subject thal she strove to allain. Why did ste call it Speceh and Drama? She herself says meder the lale of Specele and I rama, since people in the twent ieth century have frivolous

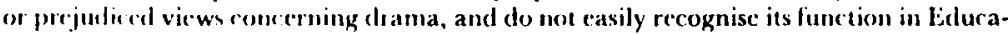
time" (af also the following footnote).

17. Compare this with Prof. Sinedeton's statement (ibid. p. 10) that Drama is the art form of the

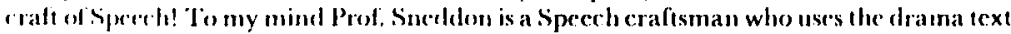
merely (1) allain her objertives as regatds Sperch as a means ol communication and or Inlerpreldtion and or Sicech ("I ratua") education.

18. (Buce again the RSA came inte contact with this method ria Britain, under the impression that it came into existene there (ef. Terry, 1982), while developments there, in the middle sixlies, should be ascribed to the many articles and books on the subject which started appearing towards the end of the lorties in the 1 S.I (ct. Siks, 1958). 


\section{Training of speech and theatre experts}

meant for an audience outside the classroom. Cireative dramatics is not, therefore, a separate subject in the school curriculum, but it is an educational aid and a teaching method which uses theatrical techniques by means of which children may learn while playing and creatively "discover" and master the learning content. It is handled by the tcacher who has had special training in this technique at the department of 'l theatre-in-Lducation at a university or a teachers' training college. Voice, specch, language usage, communicative ability, posture, concentration, observation and imagination - all these are qualities of the children which are gradually and naturally developed and improved.

Ultimately these three subjects ought to grow into being three scparate departments. Each of these departments should strive to have a fourth Speech department instituted at each university in the RSA: a logopedics department. Doctoral study in all four departments is both feasible and desirable.

The lecturers of the single subject Speech and Oral Interpretation in the present "drama" department at the PU for CHE do their utmost to fulfil all these nceds. Of course they are badly hampered by the lack of money, staff, time and facilities in their eflorts to attain this ideal. It is, however, really cssential that the existing subject should be subdivided into two separate subjects as soon as possible: Speech Communication and Oral Interpretation (Theatre-in-Education can follow later). Under present circumstances there is no possibility of growth and development.

\section{THE THEATRE SGIENCE DEPARTMENT}

The general objective of this department should be to nurture intelligent, well-read and informed theatrical audiences in South Africa. The following subjects should be offered:

\section{Theatre science}

This subject should attract and train as many students as possible who are interested in the theatre and its arts without necessarily wanting to participate actively in the professional side. The history of theatre, milicu, technical analysis of text, theatre criticism, the arts and crafts of the theatre and playwrighting should be studied from the starting point of a real stage production. These students should be encouraged to attend auditions and rehearsals and to work behind the scenes as stage managers, light and sound 


\section{Scheepers}

operators, makc-up artists, costumiers, décor builders, props mistresses, etc. in the academic theatre, so that they could get to know the theatre in its totality. Theatre Science $I I I$ should be an academic qualification for the B.A. degree rather than a professional qualification. Students who obtain this degree can then become fully fledged members of a theatre audience who can critically and judicially appreciate what is offered on stage, on film, on $T V$ and on radio. Apart from the general educational and cultural value of such a course it also offers valuable background knowledge for the student wishing to be trained as a teacher of literature. At the post-graduate level this subject should be aimed at training playwrights, directors, theatrical historians, theatrical philosophers, reviewers and critics as well as lecturers professionally.

\section{Theatre Arts (Toneelkunde)}

The courses in this subject should be aimed at developing the emotional freedom, the imaginative power, expressive ability, ability to concentrate and powers of observation of the "actor" playing in productions in the academic theatre from the first year. The timetable periods should be used to develop his acting and technical abilities to the extent that it will be to the advantage of the production in which he is involved. He applies this knowledge, as well as the theoretical knowledge which he gained in the rlasses on 'T 'heatre Science, in his rchearsals of the stage productions, and along this way he then gains an integrated theatre training (Jansen van Renslourg, 1976, p. 234), which was also Stanislavski's primary objective with the training of actors (ibid., pp. 219-220). In a post-graduate diploma course, where the student of Theatre Arts can use cvery day of the academic year fully for his training in stage practice, the objective should still not be to acquire the already existing techniques as prescribed by the professional theatre without any more ado, simply imitating these, but should be to experiment with new techniques which might lead to the development of acting in the country. Although the students who follow this course at the university should, to my mind, be limited to the talented handful, the activities of the Academic Theatre should be open to all interested students at the university.

Each 'Theatre Science department should work towards the establishment of a separate Film and 'TV depar/ment at each university in the RSA. The field of study of Film and 'TV differs considerably from the field of study of the theatre. Mutual co-operation in certain fields between the two separate departments, however, is highly desirable and possible. 


\section{Training of speech and theatre experts}

The Theatre Science section of the existing "drama" department at the PU for CHL offers both the above subjects according to the objective and the method that is advocated: Theatre Science (still called Drama [Dramakunde]), and Theatre Arts (Toneelkunde). Theatre Science justifics doctoral study. The post-graduate work in Theatre Arts, however, should be aimed at the profession and at actual theatrical practice.

The proposed division, which at first glance may seem idealistic, is not therefore so unattainable ${ }^{19}$ ! But in this too the shortage of staff, money, time, and especially the lack of a well-equipped theatre and training facilities militate against the cffective functioning of a department of which stage productions should in reality constitute the core, the central focus and the point of departure of all study of the humanities at the university (cf. Scheepers, 1980, pp. 37-41).

Sceing that the academic theatre should be regarded as a research laboratory and a library in live form, the stage productions should be of a high professional standard. Post-graduate courses should be instituted, and guest art ists - actors and directors - should be invited to the academic theatre with the purpose of keeping int act the standard of the campus productions.

The ultimate aim of each department of Theatre Science/Arts should be to extend its academic theatre and to develop to a fully-fledged professional theatre where the best post-graduate students can remain to study while they are working and doing research, in their programme to become theatre lecturers, directors, etc.

It is essential for the growth and the development of the THEATRE in the RSA that the present Councils for the Performing Arts should be decentralized further. Their purpose, as they exist at the moment, has become obsolescent. If Potchefstroom and the vicinity should have been dependent for its theatre only on the offerings of PAC'I', there would have been a theatre famine herc. The Theatre Arts section of the "drama" department at the PU for C.HE is responsible for seven major stage productions, five or six lunch hour programmes and four revues per year,

19. Mr J. HI. Niemand suggested, after reading my thesis, that this ideal would only be realized alter 25 years, berause cverything in the RSA only happess 25 vears later. l'rol. Teunis Botha is more pessimistic and suggests 50 years! To my mind we have alrearly wasted enough time int a rul-ele-sac. 


\section{Scheepers}

which are very well supported by both students and public. Programmes are also taken to the schools, and it is thus justified to claim for this Department a share of the government subsidy, a properly cquipped theatre with full training facilities, etc. in order to extend their activities to other parts of the Western Transvaal (parts at present skimpily treated by PACT mainly because of the extensiveness of the territory). A professional theatre can grow out of the Theatre Arts departments at the universitics which can only be to the advantage of the theatrical activities of the entire country.

This professional lnst itute or Conservatory for Theatrical Arts at university campuses could bring more stability and prospects to the scientific and acadenically trained actor, director, designer, technician etc. than is the case at the moment. A student of 22 is too young and inexperienced to enter the professional theatre, which demands of the university to supply a fully trained and shaped product. All the students who are allowed to obtain. Theatre Arts III at the PU for CHE have an above-normal level of intelligence, and have the potential or talent one day to become (possibly) a good actor, lecturer, director, designer, technician, etc. 'The Regional Councils however, refuse to accept these students as apprentices in the thratre (Swart, 1978, p. 38). They still need a further five to ten years in order to develop their intellectuai and other abilities and to attain maturity. At the moment those young actors who do pass an audition are absorbed in a playwork group, where they stagnate, because they are not allowed, and do not get the opportunity, to develop any further: the most essential voice, movement, and improvisation exercises which they should be doing every day fall by the wayside. Where they do receive these, they are regarded as an extra attraction ("amenity" - ibid., p. 41); for two, three or four years they are given no opportunity to play a big role; they are not expected to think, to create, to use their intelligence or to develop intellectually; their posts are permanently in jeopardy, because they never know whether their contracts are going to be renewed, etc. etc.

The linal year students on the campuses are only too conscious of the disparities, envy, instability, uncertainty, professional jealousy and decadence at certain levels in a profession which should be aimed at the deployment and the promotion of art in general and theatrical art in particular. Instead of being alble to realize their fervent ambition and to fulfil their vocation and to be trained more fully in the profession of their choice, by, for example, entering for the post-graduate diploma in Theatre Arts, they prefer to deny their vocation and to go and teach or to do anything where, at any rate, they will earn double the salary which they would be paid in the professional theatre anyway. 


\section{Training of speech and theatre experts}

The newest trend in the RSA is that the inspired students of theatre arts who have completed their studies establish their own companies. These companies are often responsible for the only liring and lopical theatre in the country. I would like to see the universities ollering these companies of enthusiasts a home on their campuses. Here their original and creative abilitics might grow and mature and their intellectual vitality could be used to the advantage of the university and the cnvironment to which they belong.

I am convinced that such a professional theatre, institute or conservatory on some campuses, the Potchefstroom one at any rate, would offer the only solution for this dilemma.

In such a professional theatre, institute or conservatory - and then, by 'professional' is meant professional in functioning and performance and practice of the theatrical arts - on the university campus the theatre lect urer can remain a member for as long as possible. Then the objection that unprofessional people or people not involved in the profession, or nonprofessionals - and by that is usually meant lecturers who do not know the 'tricks of the trade' are used to train the students will also not be valid any more.

The Theatre Arts/Science sections in the "drama" departments of the universities in the RSA should abandon their apologetic attitudes in the full a wareness that the study of the theatre and its arts is scientilically grounded an academically justifiable. They should assume their rightful place in the theatre with self-confidence: as leaders, shapers of idcas, and makers of method. They should put their knowledge and expertise at the disposal of the profession and so contribute to the growth and stronger development of a living and topical theatre in the RSA.

\section{REFERENCES}

BOSMAN, F.C.L. 1952. Verslag oor besenek vir studie van toneed in die Verenigde State van Amerika, Septenuber tot Desember ISSO. Pretoria : NRSN.

BOTH 1 , T, 1964. Besock aan die universiteite van Natal, Stellenbosch en Kaapstad gedurende Oktober l964. (Unpublished report, PU lor (:HE in Srhecesers, 1978, p. 572-9).

BO'IHA, 'I: I969. Dic Iraterlertog, (;corg II ran Sakse-Nciningen; in waardebepaling, hoofsouk 1. Perspettir/, p. 14-44. Potchefstrom : Pro Rege Pers.

BC 'THA, T. 1970. Die opvoedkundige teater: 'n verkeming. (Lnpublished inaugual lecture - Potchefistroom : Pl lor (:IIli).

BR.ADBSY, I). 1978. Drama in the universities. Sfrees amd drama. 27(1):29-38.

BROWN, J.R. 1967. A university and the theatre: an inaugural kecture dedisered in the University of Birmingham on 26th ()ctober, 1967. Birminghans : Sutcons. 


\section{Scheepers}

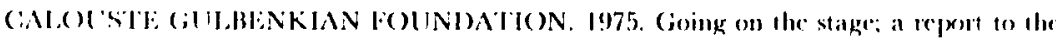

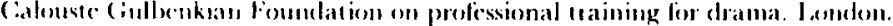

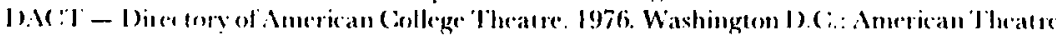
Asocintiun (Ali).

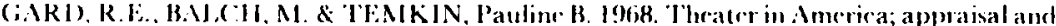
challenge for the National Theatre Comlerence. New York : Theatere Arts Besks.

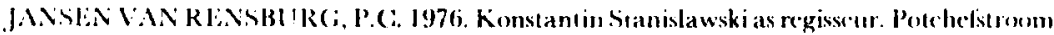
(Inpuhlished b) litt.-thesis - Pli lor (:HE.)

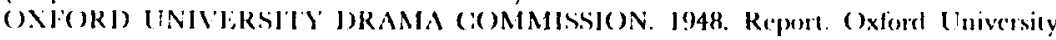
l'res.

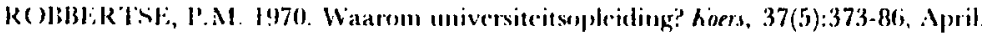

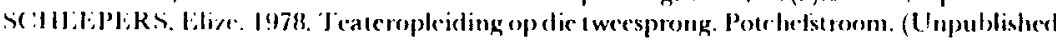

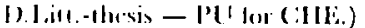

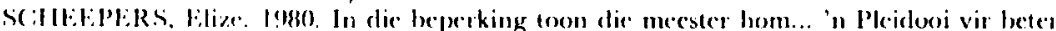
versorging van die dramatepartemente an de univesiteite in die. RSA. Teraer/orum. I(I):374l. Mr.i.

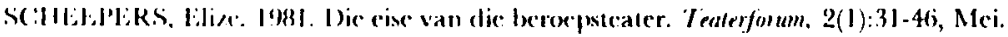

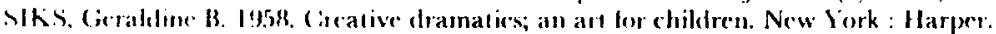

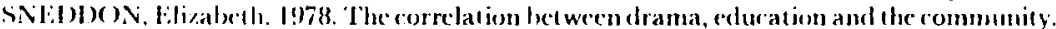

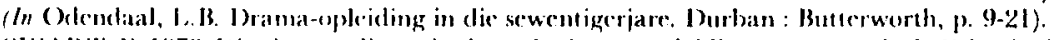

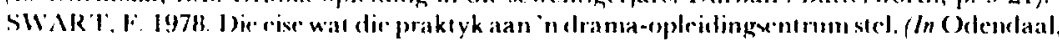

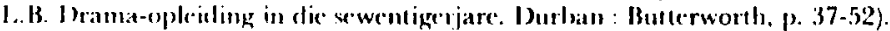

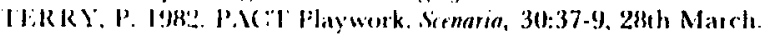

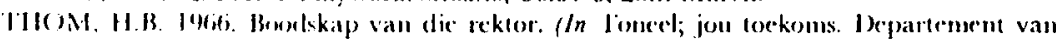

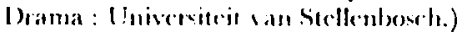

IVNABLAS. M. IU76. So you want to be an actor? There's much mole to it than just theory..

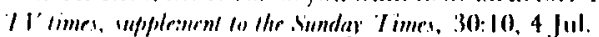

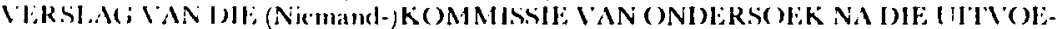

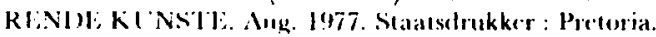

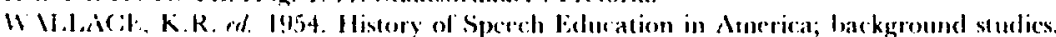
New lork: Appleton. 